Institute of $\mathbf{F}_{\text {ood and }} \mathbf{A g r i c u l t u r a l}_{\mathbf{S}} \mathbf{S}_{\text {ciences }}$

\title{
Housing As We Grow Older: Community Support Services ${ }^{1}$
}

Virginia Peart and Carolyn Wilken ${ }^{2}$

When planning for retirement, the community where you will live is important. Take a close look at the services offered and how well they match your needs and interests.

A community must be tuned in to "senior power." It should be a caring community with programs for older adults which recognize and make the most of their wealth of knowledge and skills.

Be sure to find out how a community meets the needs of older citizens. Consider the following:

- Does the community offer employment resources (hobby items, part-time jobs, new careers, adult education teachers, consulting opportunities)?

- Are older volunteers welcomed by community agencies (foster grandparents, library and school aides, drivers, tutors)?
- Are learning opportunities available? Back-to-school? High school equivalency? Enrichment and courses for credit or non-credit? Adult education classes?

- Do services meet the needs of older adults? Are repairmen available for service calls? Are charges fair? Are complaints resolved? Are salespersons honest?

- Do stores meet the needs of older adults? In pharmacies, are prescription drug prices listed? Are generic or brand-name drugs available? Do restaurants, buses, beauty shops and barbers, movies, grocery stores, and others offer discounts to senior citizens?

- Are services available to help older citizens live in their own homes? Home nursing? Home-delivered meals? Grocery

1. This document is Fact Sheet FCS 3191, a series of the Department of Family, Youth and Community Sciences, Florida Cooperative Extension Service, Institute of Food and Agricultural Sciences, University of Florida. Publication date: November 2002. First published: January 1994. Revised: November 2002. Originally published as SAH-4. Adapted for use in Florida from "Housing as We Grow Older: Community Support Services," prepared by Joseph L. Wysocki, former Family Living Specialist at Pennsylvania State University; and "Tomorrow's Choices," PF4224(1290)D13479, prepared by the American Association of Retired Persons. Please visit the EDIS web site at http://edis.ifas.ufl.edu

2. Adapted by Virginia Peart, former associate professor, Housing; revised by Carolyn Wilken, associate professor, Family Life; and reviewed by Nayda I. Torres, professor, Family and Consumer Economics, Department of Family, Youth and Community Sciences, Cooperative Extension Service, Institute of Food and Agricultural Sciences, University of Florida, Gainesville, 32611. 
delivery? Chore services? Homemaker services? Home health aides?

- Are legal services available?

- Are ambulance services, county home health aides or nurses, homemaker services, home-delivered meals available?

- Are a variety of housing options available? Do these include minimum-care and extended-care facilities, nursing homes, senior citizen housing?

If you decide to move, what do you want to gain from your new area? What are you happy to leave behind? What would you be sad to leave behind? How will a new community fill the gaps?

Before making a final decision, make two lists. One list for the advantages of the move and the other for the disadvantages or those reasons why you will miss your present home. Start looking at new neighborhoods before you need them. Look at your lists again at least a month before deciding on a move.

Also, if you are married, consider what that community has to offer a single person as well as a couple. Although losing a partner is not a pleasant thought, it is a realistic and important consideration for retirees.

\section{Special Services to Assist the Aging}

Most older persons want to remain independent and live at home. Even if you develop some physical or mental limitations, there are a number of services available in many communities to help you stay in your home and live independently. There are some questions you should ask when thinking about services to help you stay in your home:

- Your Area Agency on Aging can provide information. It is usually listed in your telephone directory under the Local Government heading.

- What does each service cost? How much of the cost can be paid for through Medicare? Medicaid? Other insurance?

- If you need several services, does the cost of all of them added together become too expensive?

- Can you count on family or friends to help out? On a regular basis? Occasionally? Financially? With transportation?

- Does your home have barriers to those with physical disabilities? Can it be modified if needed?

Family and friends can't always provide for all of your needs and wants. They may live too far away or have other demands to complicate their lives. Neither you nor they should feel guilty about this or reluctant to ask for outside help. Talk this through and come up with a "plan of action" that is realistic and best for all concerned.

\section{Friendly Visitors}

Friendly visitors are volunteers who regularly visit older persons who need companionship. They may read, write letters, run local errands, etc. 
Cost

No Charge

Availability

Varies. Usually provided

by a religious or voluntary organization. Contact your church or synagogue or the Visiting Nurses Association to see if the service is available in your community.

\section{Telephone Reassurance}

Telephone Reassurance is offered by volunteers who talk to elders daily to ensure that "all is well." This service is especially helpful to people who live alone.

$\begin{array}{ll}\text { Cost } & \text { No Charge } \\ \text { Availability } & \text { Varies. Contact your Area } \\ & \text { Agency on Aging, church } \\ & \text { or synagogue, or Visiting } \\ & \text { Nurses Association. }\end{array}$

\section{Homemaker Services}

Homemaker services include help with grooming and dressing, and with meal preparation, food shopping or light housekeeping.

Cost

Availability
Around \$10 per hour. Usually not covered by Medicare, Medicaid and Medigap insurance. Coverage varies by state and by policy, respectively. Some provider agencies have no charge for lowincome persons for 4 to 8 hours per week, however there is sometimes a waiting list.

Widely available. Contact your Area Agency on Aging for information.

\section{Home Chore Services}

Home chore services offer minor household repairs, household cleaning and yardwork.

Cost

Average $\$ 5$ per hour, plus materials. Free or reduced-rate programs may be available through the Area Agency on Aging.

Availability Widely available. Contact your Area Agency on Aging for information.

\section{Home Health Care}

Home health care covers a wide variety of medical services provided by professionals such as a nurse or physical therapist.

Cost

Costs can range from $\$ 25$ per visit for 1 to 2 hours by a registered nurse to $\$ 50$ per visit for a therapist. Medicare, Medicaid, and Medigap insurance may all cover some home health care costs, depending on the service and the policy. Medicare will pay only if the patient is confined to home and requires parttime nursing care or therapy under a plan set up by a doctor. Dollar limits are set on payments for each type of service and the consumer must pay the difference between the Medicare limit and the actual cost. Check with your local Social Security office.

Availability Widely available. Contact your Visiting Nurses Association or your Area Agency on Aging. 


\section{Home-Delivered Meals}

Home-delivered meals or "meals-onwheels" is a service that delivers hot, nutritious meals once or twice a day, usually five days per week. Most home-delivered meal programs can provide foods for special diets.

Cost

Usually $\$ 2$ to $\$ 4$ per meal. Some programs have a sliding scale fee determined by your ability to pay.

Availability Widely available. Contact your Area Agency on Aging for information.

Many of these in-home services require that a stranger come into your house. The services referred by your Area Agency on Aging will be bonded and aides will be trained and checked for reliability. If you locate help on your own be sure to:

- Ask for and check out the references of the agency providing the service. It should be bonded. Ask if it is a member of the Better Business Bureau or Chamber of Commerce.

- Ask for and contact the aide's references. Be sure the aide has been trained to perform the required duties.

- When the service is to be performed on a regular basis, settle all arrangements for paying the aide, transportation costs, Social Security, or other fringe benefits before the aide starts work.

- Find out who is legally responsible if anything is stolen by the aide or if the aide is involved in an accident in your home.
- Make a list of tasks and working hours before every visit of the aide. Insist that the aide follow your schedule.

- Require receipts for all purchases the aide makes for you during shopping trips.

- Give the aide a list of emergency telephone numbers.

- Call the supervisor with any compliments or complaints about the aide's performance. Contact your Better Business Bureau if the agency doesn't respond to your complaint.

- Dismiss the aide if you are not satisfied with the service.

\section{Assistive Devices}

Assistive devices are services and products that can be purchased or rented to help a person function better at home. These may include devices for people with hearing problems, people with vision problems, and those who need help in walking or moving about.

\section{For People with Hearing Problems}

- Alerting devices that tell when the doorbell, smoke alarm, or alarm clock is ringing,

- Amplification devices that make it easier to hear telephone callers,

- Telecommunication Devices for the Deaf (TDDs) that translate voice conversations into print so that people with hearing 
problems can make their own telephone calls,

- Telecaption adapters for TVs to allow people to read captions on screen.

\section{For People with Vision Problems}

- A wide variety of products with braille or large type (e.g., watches, pushbutton phone attachments, kitchen utensils, and blood pressure kits)

- Tape-recorded books

- Radio reading services

\section{For Those with Mobility Problems}

- Walkers, canes, wheelchairs

- Grab bars for bathrooms, hallways, etc.

$\begin{array}{ll}\text { Cost } & \text { Costs vary greatly } \\ \text { depending on the product. } \\ \text { Medicare may pay for the } \\ \text { rental or part of the } \\ \text { purchase price for } \\ \text { wheelchairs, walkers, or } \\ \text { other devices if they are } \\ \text { prescribed by a doctor. } \\ \text { Widely available. } \\ \text { Assistive devices may be } \\ \text { available from medical } \\ \text { equipment rental stores or } \\ \text { electronic product stores. } \\ \text { There are a number of } \\ \text { catalogs that have } \\ \text { assistive devices. }\end{array}$

\section{Personal Emergency Response Systems -- (PERS)}

PERS are emergency alert button devices that are placed in your home and can be pressed to summon help from emergency response centers such as hospitals or 800 numbers.
Cost

Availability

\section{Home Maintenance and Repair Programs}

Home Maintenance and Repair Programs (usually sponsored by nonprofit organizations) provide home maintenance, home repair and help with housing emergencies such as frozen pipes. No major improvements or cosmetic changes are included. Some programs will help elders work with contractors.

\section{Cost}

Often for a small annual fee (around \$10) you get one annual visit and access to emergency services and reduced rates. Some programs offer free labor, if you supply materials.

Availability Widely available. Contact your Area Agency on Aging for information.

\section{Other Programs and Services}

In the Foster Grandparent Program older men and women serve as foster 
grandparents to youngsters. The program provides a job opportunity for low-income persons over sixty years of age who work on a one-to-one basis with children.

\section{Retired Senior Volunteer Program} (RSVP). Under RSVP, senior volunteers serve in a variety of public and private nonprofit agencies, including courts, schools, libraries, day care centers, hospitals, nursing homes, Scout offices, economic development agencies and other community service centers.

Some communities offer a wide range of services for elders. Find out about the possibilities in your community or future community. Support services in a community provide a variety of services you need and the community, in turn can benefit from your unique contributions.

Leisure Activities. If you do not have a hobby, here are some questions to help you choose one before retirement. Do you enjoy being with people or prefer being alone? Do you enjoy present friends? Do you make friends easily?

Some popular hobbies are: cards, bowling, antiques, local history, genealogy, youth work, handcrafts, cake decorating, pottery, reading, quilting, woodworking, rock polishing, chess, bicycling, music, hotline volunteer, business consultant. The list is endless. The decision is yours.

Many communities, especially college or university communities, offer cultural and sports events at reasonable rates. Other college-related opportunities worth investigating are tours and other alumnisponsored opportunities. Many social groups offer reduced rate travel packages for senior citizens.

Part-Time Work. Some communities actively recruit senior citizens for part-time job opportunities coordinated by a central agency. 